\section{STUDIES ON THE MODE OF ACTION AND STRUCTURE OF GLUCONIMYCIN}

Sir:

In 1966 an antibiotic was isolated from a streptomycete and named gluconimycin by SHIMI and Dewadar. This antibiotic was tentatively characterized as an iron-containing oligopeptide of the sideromycin type ${ }^{1)}$. In the course of investigations on iron-containing metabolites (for a review see ref. 2) we resumed the work on this antibiotic. While studying the mode of action it became apparent that the active substance from Streptomyces AS 9 strongly inhibited macromolecular synthesis similar to the action of members of the actinomycin group.

Fermentation was performed as described ${ }^{1)}$. The antibiotic was extracted from the culture fluid by ethyl acetate, the extract was washed with sodium carbonate buffer at $\mathrm{pH} 10$, several times with water and concentrated to dryness. The raw material was precipitated from a chloroform solution by petroleum ether. At this purification stage the product showed one spot in paper chromatography on Whatman No. $1^{1)}$, but sever- al spots of yellowish to red coloured substances and UV absorbing material in TLC on silica gel using chloroform - methanol - water $=65: 25: 4$ as a solvent. Only three of them showed antibiotic activity against Bacillus subtilis in a bioautogram. Chromatography on Sephadex LH20 (eluant; methanol), silica gel (eluant; chloroform with $0 \sim 5 \%$ ethanol), cellulose (eluant; methanol) and preparative TLC (solvent; ethylacetate - propanol-2 - water $=5: 2: 1$ ) yielded an almost homogeneous preparation of the main product (A).

Biophotometer studies revealed that substance A inhibited growth of Bacillus subtilis ATCC 6051 and Micrococcus luteus ATCC 15932 effectively at $2 \mu \mathrm{g} / \mathrm{ml}$ and $0.2 \mu \mathrm{g} / \mathrm{ml}$ respectively. Escherichia coli was not inhibited at $1 \mathrm{mg} / \mathrm{ml}$ in the agar diffusion test. In vivo tests of macromolecular synthesis were done with Micrococcus luteus, as this microorganisms proved to incorporate ${ }^{14} \mathrm{C}$-thymidine for the measurement of DNA synthesis. Results are shown in Fig. 1.

To confirm these results, the inhibition of DNA and RNA polymerases was studied in vitro, and $50 \%$ inhibition of DNA polymerase I of $E$. coli and RNA polymerase of $E$. coli was observed at

Fig. 1. Inhibition of a) protein and DNA synthesis, b) RNA and DNA synthesis by gluconimycin in Micrococcus luteus. The arrows indicate the time of addition of the antibiotic.

a)

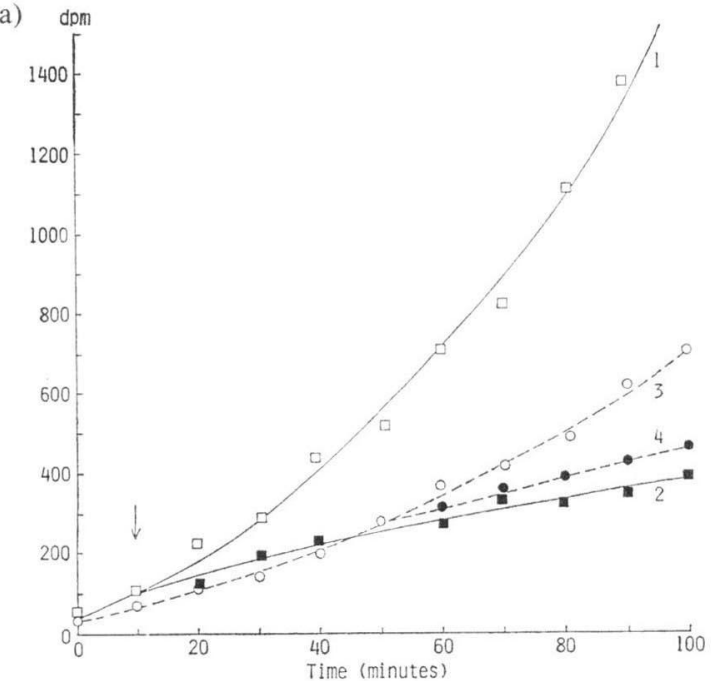

b)

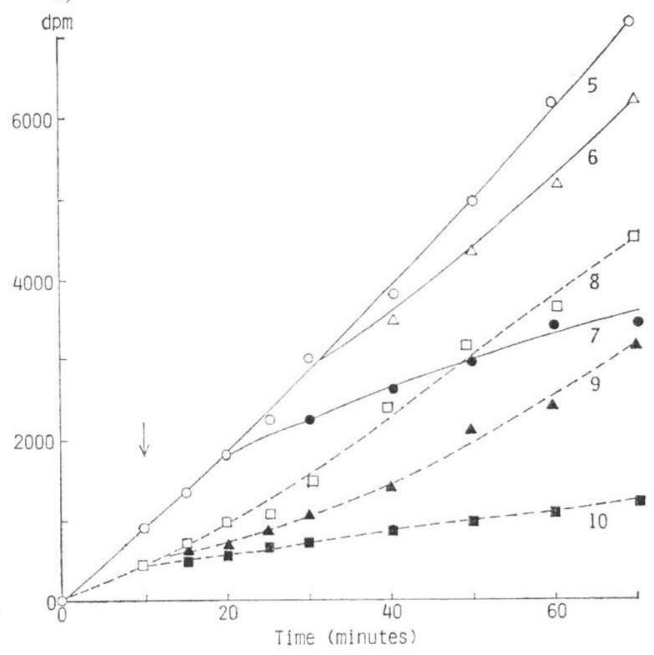

\begin{tabular}{l|c|c|c|c|c|c|c|c|c|c}
\hline & 1 & 2 & 3 & 4 & 5 & 6 & 7 & 8 & 9 & 10 \\
\hline Labelled compound & $\mathrm{T}$ & $\mathrm{T}$ & $\mathrm{Lys}$ & $\mathrm{Lys}$ & $\mathrm{U}$ & $\mathrm{U}$ & $\mathrm{U}$ & $\mathrm{T}$ & $\mathrm{T}$ & $\mathrm{T}$ \\
Gluconimycin $\mu \mathrm{g} / \mathrm{ml}$ & - & 0.5 & - & 0.5 & - & 0.1 & 0.5 & - & 0.1 & 0.5 \\
\hline
\end{tabular}

$\mathrm{T}$ : thymidine, Lys: lysine, $\mathrm{U}$ : uracil. 
$5 \mu \mathrm{g} / \mathrm{ml}$. DNA polymerase of calf thymus was scarcely inhibited at $20 \mu \mathrm{g} / \mathrm{ml}$.

Substance A was an orange-yellow powder, sparingly soluble in water, soluble in methanol, ethanol, acetone and chloroform, insoluble in petroleum ether. The UV spectrum showed a single absorption band at $442 \mathrm{~nm}\left(\mathrm{E}_{1 \mathrm{~cm}}^{1 \%}\right.$ in methanol $=100$ ). Hydrolysis in $6 \mathrm{~N}$ hydrochloric acid for 24 hours at $110^{\circ} \mathrm{C}$ and separation of the amino acids by two-dimensional TLC on silica gel yielded Thr, Val, Pro, Sar, MeVal and MeAla (1. 1-butanol - acetic acid - water $=4: 1: 1 ; 2$. phenol - water $=75: 25$ ). The Thr-spot was broadened. Therefore, the occurrence of hydroxy-threonine or another unknown amino acid cannot be excluded.

Gluconimycin differs from the actinomycins of the Z-group by the presence of proline. The amino acid composition of gluconimycin is similar to that of actinomycins of the X-group. In circular paper chromatography (solvent; $n$ butyl acetate - di- $n$-butyl ether $=3: 1 / 10 \%$ aq. sodium- $m$-cresotinate) the $\mathrm{R}_{\mathrm{fC}_{2}}$-value was 0.48 , which is between the reported values for $\mathrm{X}_{0}$ and $X_{1}$. TLC on silica gel (solvent: ethyl acetate propanol-2 - water $=5: 2: 1$ ) gave an $\mathrm{R}_{\mathrm{fC}_{2}}$-value of 0.79 for gluconimycin and 0.97 for actinomycin $X_{1}$. The NMR-spectra indicated non-identity of the two peptide chains and the absence of keto derivatives. 4-Hydroxy-L-proline, which is present in the actinomycin $\mathrm{X}_{0 \beta}$ and $\mathrm{X}_{0 \tilde{\delta}}$, is definitely absent. The low mobility in paper chromatography, the solubility in water and the NMR-spectra point to the presence of an unidentified hydroxycompound. Furthermore, Nmethylalanine has not been found so far in actinomycins of the $\mathrm{X}$-series ${ }^{3)}$. The low productivity of the strain and the obvious instability of the compound hindered further identification.

From our results it is concluded that the main active compound from Streptomyces AS 9 is an actinomycin which has hitherto not been described. The biological activity of the formerly iso- lated product is - as far as it had been testedidentical to that compound described in this communication.

\section{Acknowledgments}

The authors wish to express their thanks to Prof. H. LACKNER, Universität Göttingen for the NMR spectra, Dr. G. Krauss, Medizinische Hochschule Hannover, for help with the in vitro tests of DNA and RNA polymerases, and Dr. G. AuLING for discussions. This work was supported by a grant from the Stiftung Volkswagenwerk.

\section{Hans-Jürgen Plattner \\ Barbara Stens \\ HANS DIEKMANN*}

Lehrgebiet für Mikrobiologie der Universität Hannover, Schneiderberg 50, D-3000 Hannover, Federal Republic of Germany

IBRAHIM R. SHIMI

Department of Biochemistry, The University of Ain Shams Abbassiah, Cairo, Egypt Arabic Republic

(Received May 9, 1980)

* To whom all correspondence should be addressed.

\section{References}

1) Shimi, I. R. \& A. Dewadar: Gluconimycin, a new antibiotic. Arch. Microbiol. 54: 246 252, 1966

2) MAEHR, H.: Siderochromes. in Antibiotics, Isolation, Separation and Purification. Journal of Chromatography Library. Vol. 15 (WEINSTEIN, M. J. \& G. H. Wagman eds.), pp. $521 \sim 585$, Elsevier Scientific Publ. Co., 1978

3) Mauger, A. B. \& E. Katz: in Antibiotics, Isolation, Separation and Purification. Journal of Chromatography Library. Vol. 15 (WeInstern, M. J. \& G. H. WAGMAN eds.), pp. $1 \sim 38$, Elsevier Scientific. Publ. Co., 1978 